\title{
Strategic Analysis of Turbine Manufacturing Development in Achieving Required Local Content
}

\author{
Rislima F. Sitompul \\ ${ }^{\#}$ Research Center for Science, Technology and Innovation Policy and Management, Indonesian Institute of Sciences (P2KMI-LIPI), \\ Jakarta 10270, Indonesia \\ E-mail: rislimafs@gmail.com; risl001@lipi.go.id
}

\begin{abstract}
The government of Indonesia has set up an electricity development program of 35,000 Mega Watt (MW) to provide adequate electricity infrastructure so that the $100 \%$ electrification ratio can be achieved. The construction of the development of power infrastructure has implications for the demand for reliable electrical components, which supports upstream to downstream industries. The turbine is one of the major components in electricity infrastructure which requires the supply of mechanical energy as the driving force. Despite its market potential, the turbine is a relatively high imported component, and this indicates the importance of fostering the development of turbine technology in Indonesia. The main objective of this study is to examine the capability of national turbine industries and research institutions in formulating policy recommendations to increase the use of the local content, called Tingkat Kemampuan Dalam Negeri (TKDN), in turbine manufacturing industries following the provisions stipulated in the Ministerial Decree No.54/M-IND/PER/03/2012 on Guidelines for Use of Products of State for Infrastructure Development in Electricity. This study applies SWOT and Balanced Scorecard, focusing on the analysis of capabilities of the turbine industry and identifying the mastery of turbine technology by various research and development institutions in Indonesia. The result of the study shows that the degree of BSC performance level in implementing the TKDN improvement strategy in the turbine industry is considered as less successful, therefore, short-term and long-term policy recommendation needs to be implemented to expedite the increase of TKDN.
\end{abstract}

Keywords-35000 MW electricity development program; TKDN; SWOT analysis; turbine industry.

\section{INTRODUCTION}

The development of the electricity sector is critical in the effort to accelerate the pace of economic growth and increase the economic welfare of the community. The Government of Indonesia (GOI) has set a national strategic program for electricity development of 35,000 MW, previously planned to be completed in 2019, to accelerate economic growth while overcoming the electricity crisis that often occurs in various parts of Indonesia [1]. This program is designed not only to increase electricity supply for the country but also to increase per capita consumption to $1,200 \mathrm{kWh}$ per capita by 2019 , from around $865 \mathrm{kWh}$ per capita in 2014 [2]. The level of electricity consumption per capita can represent the level of economic growth and the level of welfare of the people, which at present, the level of consumption per capita in Indonesia is among the lowest in ASEAN countries. The total installed capacity of power plants in Indonesia until the end of 2014 reached 53,065 MW, and the level of the electricity ratio reached $84.35 \%$ [2], [3].

For supporting the program, a comprehensive development effort is needed on all stages of electricity generation activities, including the procurement of turbine technology as one of the main components of the power generation system. Therefore, the involvement of the national industry to fulfill the turbine components required in national electricity development becomes very important and has strategic value in the context of the national economy [4]. However, efforts to develop turbines from within the country are still constrained by several fundamental problems, one of which is the still high level of imported components both in the power generation system and in the turbine components themselves [5]. The level of the local content, here is stated as TKDN (Tingkat Komponen Dalam Negeri) for the construction of electricity infrastructure is still lower than the target of TKDN of power plants determined under the Minister of Industry (MoI) Regulation Number 54/MIND/PER/3/2012 concerning Guidelines for Using Domestic Products for Electricity Infrastructure Development [6].

The achievement of TKDN for components of steam power plant or Pembangkit Listrik Tenaga Uap (PLTU) goods and services on a capacity scale of 100-600 MW reached at only $16.77 \%$, while the minimum requirement 
according to the Regulation of the MoI No. 54/MIND/PER/3/2012 is $40 \%$ [7]. The average utilization of TKDN in 35,000 MW projects for various types of plants, namely PLTMG (Gas Engine Power Plant)/PLTG (Gas Power Plant)/PLTU above $100 \mathrm{MW}$, is in the range of 32 percent. While for plants with a capacity of less than 100 MW, TKDN can already be fulfilled by more than 50\% [8].

Some of the products used for electricity projects are still imported, such as generators, turbines, and boilers [9]. Although the domestic capital goods industry has the potential to meet the TKDN needs of electricity infrastructure because it has been able to produce, including turbines with capacity up to $27 \mathrm{MW}$, generator capacities up to $10 \mathrm{MW}$, boilers with capacities of up to $660 \mathrm{MW}$, and capacity transformers up to $550 \mathrm{kVA}$ [10]. The condition of the high import component in electricity generation systems, especially turbines, shows that the mastery of turbine technology in Indonesia is relatively weak [4]. Ministry of Research, Technology and Higher Education (Kementerian Riset, Teknologi dan Pendidikan Tinggi), termed as Kemenristekdikti considers that it is necessary to conduct a study of the national turbine industry and R \& D institutions, focusing on identifying the capabilities of the turbine industry in Indonesia and utilization of turbine technology in power generation.

Assessing the capabilities of the turbine industry requires an effort to elaborate on the overall conditions and components of the turbine industry in Indonesia, both for technical and non-technical aspects [11]. To map, assess, plan, implement a complex industrial system, this study applies a sophisticated analysis tool that can measure current and future conditions by considering the overall internal and external factors of industry, technical and non-technical, financial and non-financial. The mapping results are useful for projecting how to improve the capabilities of the turbine industry as well as its competitive advantage by utilizing all existing factors through the implementation of strategic management systems, planning, and implementation.

In this study, the Balanced Scorecard (BSC) is used in order to assess the capabilities of the turbine industry and to measure the performance of all operational systems involved in the turbine manufacturing system. It is one of the analytical tools to measure the performance of all operational systems by considering strategic and risk factors appropriately and balance factors between internal and external factors, both long and short term [12]. This method is useful to develop a management strategy system that starts from strategic formulation up to the implementation of individual activity formulations to achieve company goals through 4 (four) perspectives, namely financial, consumer, business process, and growth-learning perspectives. In this study, the scope used is a turbine industry system with the interest of achieving the independence of the turbine industry in Indonesia.

Before the analysis using Balanced Scorecard, SWOT analysis is used as a strategic planning method to evaluate strengths, weaknesses, opportunities, and threats in the turbine industry and all operational systems involved in the turbine manufacturing system. A SWOT analysis can be applied by analyzing and sorting out various things that affect the four factors, then applying them to the SWOT matrix.

The application of SWOT and BSC measuring instruments or known as SWOT BSC, have been the most popular instrument recently. This model tool (as well as the SWOT matrix) is basically a way to create a strategic management concept when a business unit experiences a challenge and is used to explain the interrelationships of each industry's internal elements and external factors as well as measuring a company's or industry's capabilities, both technical and non-technical and useful as material for formulating policies and strategies for developing the institution. Arranging strategic management requires analysis of 8 (eight) main areas of analysis, namely: i) the history, development, and growth of the company over time; ii) identification of the company's internal strengths and weaknesses; iii) the nature of the external environment surrounding the company; iv) SWOT Analysis; v) types of company-level strategies pursued by the company; vi) the nature of the company's business-level strategy; and vii) corporate control structures and systems, and viii) how the company matches itself with its strategy [13]. Analysis of the area is embedded in the SWOT Balanced Scorecard analysis.

This study combines SWOT measuring instruments and Balanced Scorecard to become a potent performance measurement tool to achieve a balance between financial performance targets and customer performance targets, internal process performance, and HR (Human Resources) performance by integrating the four elements SWOT, strengths, weaknesses, opportunities, and threats. The study will identify and analyze using SWOT and Balanced Scorecard tools the capabilities of the turbine industry in Indonesia, and identify the level of turbine technology mastery by various research and development institutions in Indonesia.

The analysis of BSC SWOT will provide a detailed map related to the national turbine industry's capabilities and mastery of turbine industry technology, which can be used to compile policy recommendations on strategies to increase the level of local component (TKDN), primarily to support 35,000 MW electricity generation programs.

\section{MATERIALS AND METHOD}

The purpose of the study is first to identify the development of the turbine industry and the capabilities of research and development institutions in increasing the level of competitiveness of turbine technology, especially on the use of local content (TKDN) to support the 35,000 MW power generation programs. The second purpose is to improve the utilization of turbine technology that will increase the level of competitiveness by designing thorough policy recommendations, especially in the electricity sector in Indonesia mastery of domestic turbine industry technology that supports 35,000 MW power generation programs.

The data collection to achieve the goal of the study is obtained through several methods as follows:

- Desk study using data collected from research reports as well as websites of related agencies, e.g., Electricity State Own Company (PLN), the Directorate General of Electricity and Energy Utilization, several Regional 
Governments and Regional Statistics Offices, Central Bureau of Statistics, research institution and associations.

- Institutional survey to a few relevant agencies and ministries, e.g., the Ministry of Industry (MoI), Ministry of Finance (MoF), PLN, and Directorate General of Electricity (DJK), to collect relevant national data.

- We are conducting a Focus Group Discussion (FGD) and in-depth interviews with all stakeholders in the turbine industry.

Information gathered from FGD was summarized into variables that describe the conditions in the Indonesian turbine industry, both internally and externally, so that they can be identified as variables of weakness, strength, challenges, and opportunities according to the SWOT analysis framework. To produce a policy, the results of the SWOT analysis are analyzed concerning the vision and mission of the Kemenristekdikti so that there is harmony between the SWOT results and Kemeristekdikti's vision and mission. The results of the SWOT analysis that supports Kemenristekdikti's vision and mission are then analyzed by the Balanced Scorecard to produce short-term and long-term policies, especially to increase TKDN turbines in Indonesia. Fig. 1 depicts the flow of the determination of measuring decision variables to increase TKDN.

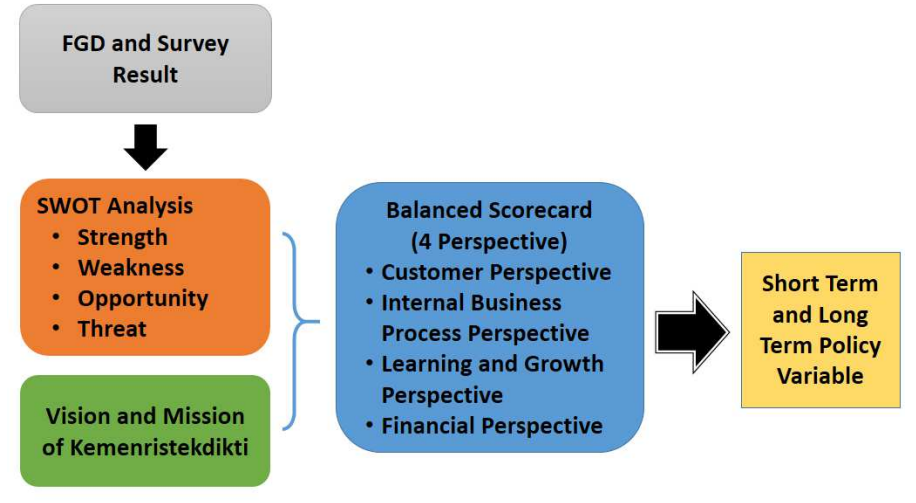

Fig. 1. Policy Analysis Flow

\section{A. SWOT Analysis}

SWOT analysis is a strategic planning method used to evaluate strengths, weaknesses, opportunities, and threats in a project or business firm where the term "strategy" refers to the art of determining how to "win" in business [14]. Recognizing existing strengths and weaknesses as well as understanding the threats, and the opportunities faced is used to map and to identify the status of development of the turbine industry and the capabilities of research and development institutions in increasing the level of competitiveness of turbine technology elaborating strategies for increasing TKDN turbines into strategic steps. The SWOT analysis is mainly intended to recognize each stakeholder in more detail and its role. Several aspects are considered in describing the strengths, weaknesses, opportunities, and threats for the turbine industry, among others are Human Resources (HR) factors and capacity building, market potential, energy potential, R \& D support, competitiveness, and innovation capabilities.

\section{B. External Factor Evaluation (EFE) Matrix and Internal Factor Evaluation (EFE) Matrix}

The External Factor Evaluation (EFE) and Internal Factor Evaluation (IFE) Matrix tools are used to summarize the information gained from the company's external and internal environment analyses [15]. These matrices are used to structure of IE matrix and play as part of the SWOT analysis. The EFE matrix in SWOT analysis is structured so that strategic planners can summarize and evaluate information based on indicators included in external factors, namely opportunities and threats, while the Internal Factor Evaluation Matrix or IFE Matrix is structured to summarize and evaluates major strengths and weaknesses in various functional areas of an organization.

\section{Assumptions in SWOT Analysis Strategy}

SWOT can be applied by analyzing and sorting out various things that affect those four factors, then applying it into a SWOT matrix, or also commonly introduced as a TOWS matrix. The SWOT/TOWS Matrix has been introduced to analyze the company's competitive situation or even four distinct sets of strategic alternatives to the leading national development [16]. The purpose of SWOT/TOWS Matrix is to create strategies based on i) strengths that can take advantage from existing opportunities; ii) weaknesses that can prevent advantages from existing opportunities; iii) strengths to deal with existing threats; and iv) handling weaknesses from creating new threats. SWOT/TOWS matrix is a combination of external and internal factors representing 4 strategies:

- Strategy SO (Strengths Opportunities) that uses all power to take advantage as much as possible of all opportunities.

- Strategy ST (Strengths Threats) that uses all available strengths to deal with threats.

- Strategy WO (Weaknesses Opportunities) that utilizes existing opportunities to minimize weaknesses.

- Strategy WT (Weaknesses Threats) that minimize existing weaknesses and to avoid threats based on defensive activities.

TABLE I

SWOT MATRIX [18]

\begin{tabular}{|l|l|l|}
\hline External & $\begin{array}{l}\text { Internal } \\
\text { Strength }(\boldsymbol{S}) \\
\text { Determine the strength } \\
\text { of internal factors }\end{array}$ & $\begin{array}{l}\text { Weakness }(\boldsymbol{W}) \\
\text { Determine the weakness } \\
\text { of internal factors }\end{array}$ \\
\hline $\begin{array}{l}\text { Opportunity }(\boldsymbol{O}) \\
\text { Determine external } \\
\text { opportunity factors }\end{array}$ & $\begin{array}{l}\text { S-O Strategy } \\
\text { Create a strategy that } \\
\text { uses power to take } \\
\text { advantage of } \\
\text { opportunities }\end{array}$ & $\begin{array}{l}\text { W-O Strategy } \\
\text { Create strategies that } \\
\text { minimize weakness to } \\
\text { take advantage of } \\
\text { opportunities }\end{array}$ \\
\hline $\begin{array}{l}\text { Threat }(\boldsymbol{T}) \\
\text { Determine external } \\
\text { threat factors }\end{array}$ & $\begin{array}{l}\text { S-T Strategy } \\
\text { Create a Strategy that } \\
\text { uses strength to } \\
\text { overcome weakness }\end{array}$ & $\begin{array}{l}\text { W-T Strategy } \\
\text { Create strategies that } \\
\text { minimize weakness to } \\
\text { avoid threats }\end{array}$ \\
\hline
\end{tabular}

\section{Key Factors for Success (KFS)}

To determine the key success factors, the elements contained in the Kemenristekdikti vision and mission need to be included. The creation of a critical success factor, which 
is a combination of SWOT analysis and Kemenristekdikti vision and mission, can be analyzed more deeply with the Balanced Scorecard analysis. Analysis of the critical success factors is done by taking the slices between the analysis of the assumptions of four SWOT strategies and the vision and mission Kemenristekdikti.

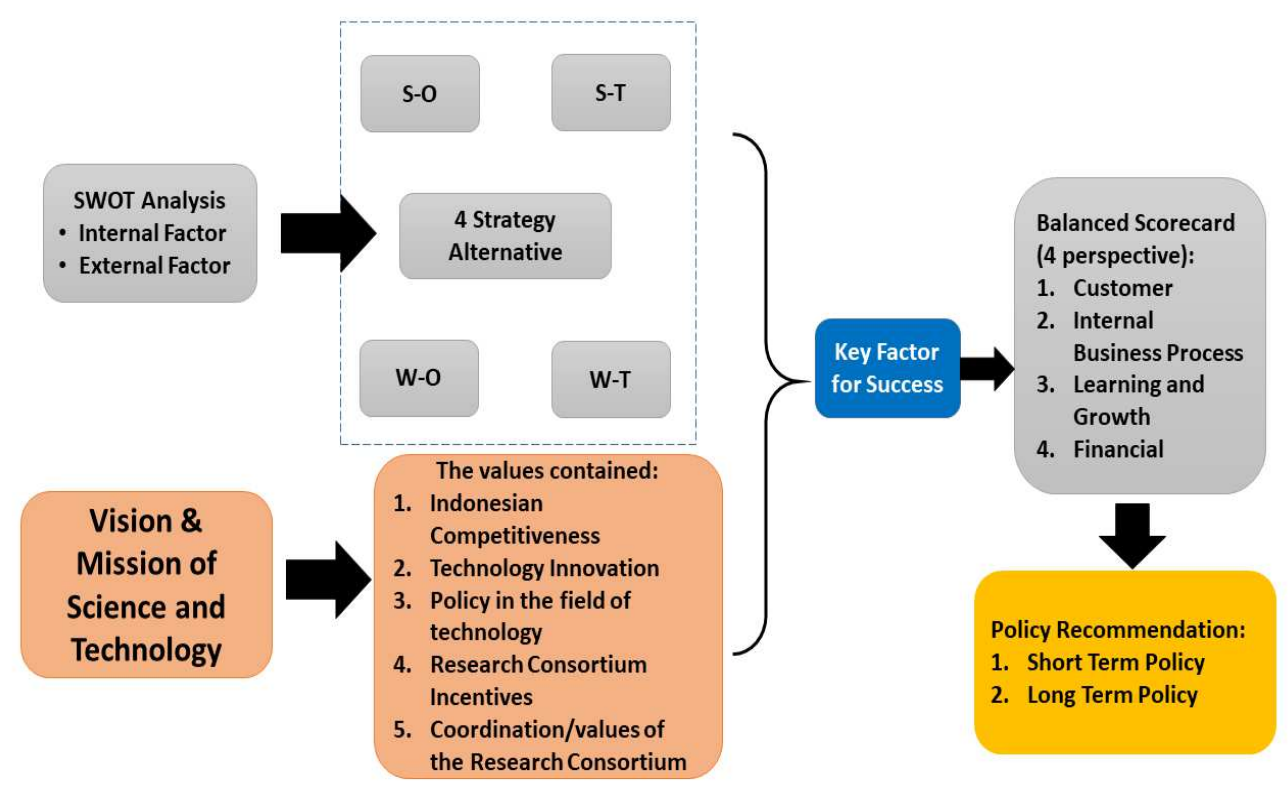

Fig. 2. Flow Chart for Determining the Key Factors for Success

\section{E. Balanced Scorecard (BSC) Analysis}

The Balanced Scorecard is a method developed by Prof. Robert S. Kaplan and David P. Norton from Nolan Norton Institute in the early 1990s [17]. The balanced scorecard is a tool for translating ministry or company vision, in which Kemeristekdikti vision and mission into a comprehensive set of performance measurements and produces a strategic management and measurement system framework, that is used not only for measuring financial aspects, but also considering three other aspects that have influences on organization, namely customer aspects, internal processes, financial aspects, and learning and growth into 4 perspectives a method of measuring performance, balanced scorecard is more than just a control system but is a method that must also be used as a system of communication, information, and learning. The BSC was not intended to substitute the financial management models, but rather as a tool of balancing the short-term activities with the set of objectives in the medium to long term (18).

The Balanced Scorecard uses four perspectives, namely:

1) The perspective of Finance: It is related to financial sustainability and is used by shareholders to evaluate organizational performance, whereas "the organization must meet the expectations of shareholders," such that it is considered successful by the shareholders.

2) The perspective of Customer: It is a customer-oriented perspective because of customers the users of the products/services produced by the organization, and the organization must pay attention to what the customer wants.

3) The perspective of the Internal Busines Process: Internal business process perspective is a series of activities that exist within the organization to create products/services to meet customer expectations.
4) The perspective of Learn and Growth: The learning and growth perspective is a perspective that describes the ability of an organization to make improvements and changes by utilizing the organization's internal resources. The sustainability of the organization, in the long run, is very dependent on this perspective

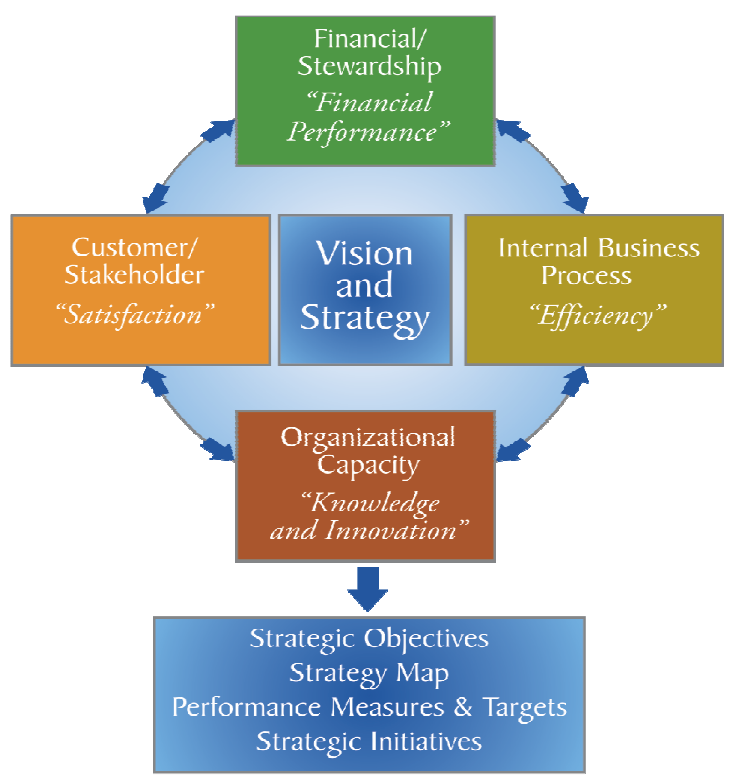

Fig. 3. Four Balanced Scorecard Perspectives

\section{F. Framework for Strategy Determination using SWOT and $B S C$}

The SWOT analysis results generated from IFE and EFE matrices are combined into an IE matrix that shows the current condition of the turbine industry in Indonesia. The results of this stage are the type of strategy according to the position of the organization in the IE matrix, which is then 
translated with the vision, mission, and objectives into the BSC perspective strategy target.

The four perspectives of BSC were then set as the key indicators. The next target strategies and key indicators will be sorted by priority and level of importance towards achieving the strategy. The results of the weighting later became the basis for compiling the managerial implications, which then will be used in making recommendations for development policy to increase TKDN of turbine industry in Indonesia. Fig. 4 presents the thinking framework for strategy determination in this study.

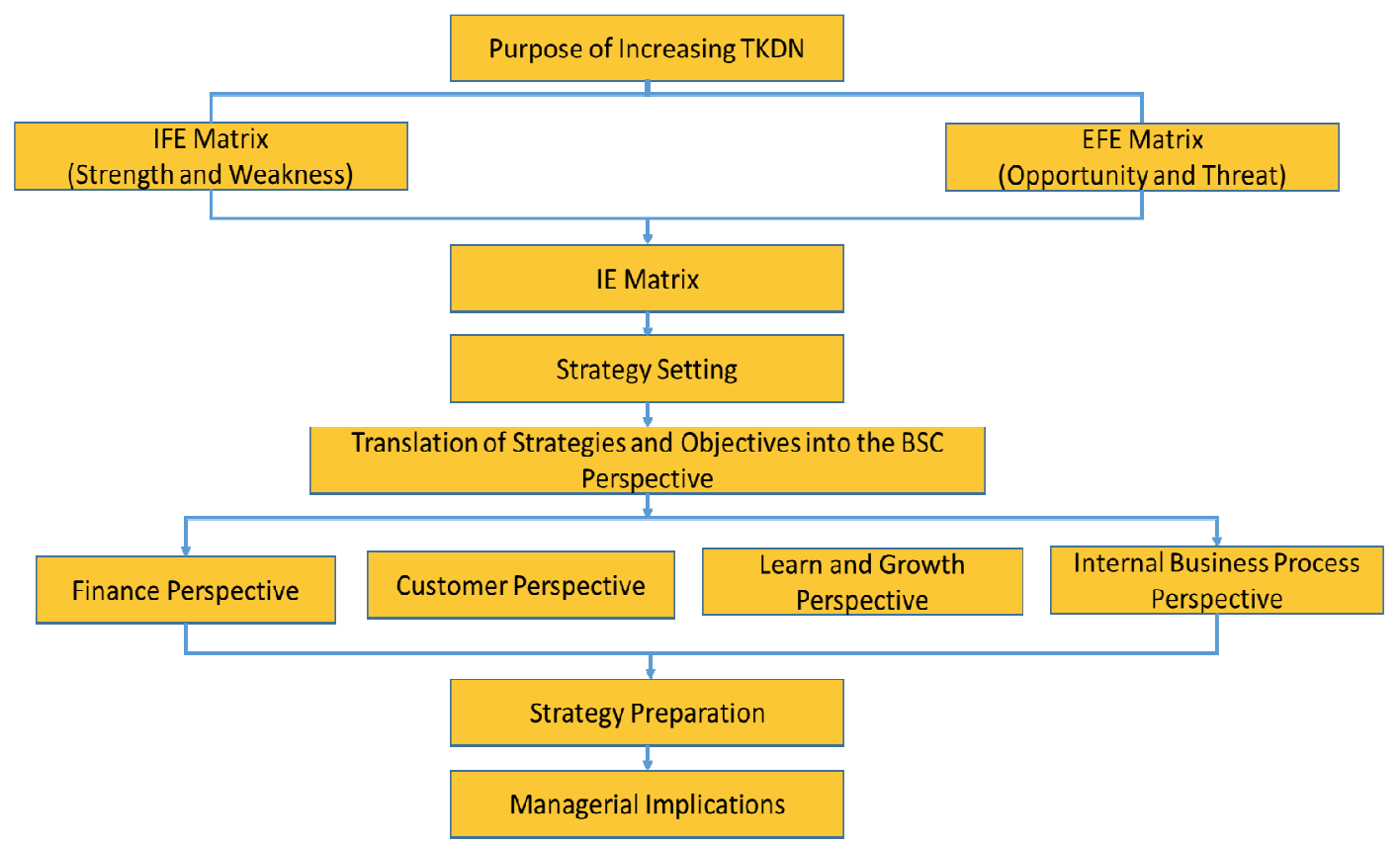

Fig. 4. Framework for Strategy Determination

\section{RESULTS AND DISCUSSION}

\section{A. SWOT Analysis}

1) Strength: Strength is a positive condition within the internal turbine industry in Indonesia that can help improve competitiveness. Some of the identified turbine industry strengths in Indonesia are:

- The availability of qualified Human Resources (HR) of turbine technology

- Turbine software technology related to turbine designs that have been developed

- Increased HR capacity in the turbine field

- Turbine technology that has been developed in Indonesia

- A huge energy market potential

- Supportive turbine R \& D in Indonesia

- Increasing turbines innovation systems in Indonesia

- The availability of supporting industries of turbine components

2) Weakness: Weaknesses are shortcomings or negative aspects found in the development of the turbine industry that can threaten the decline in competitiveness. The weaknesses are:

- Lack of supporting policies and regulation

- No market guarantees for turbine manufacturing

- Turbine testing site is not yet available

- Non-continuous mechanism of the national budget
- The number of domestically produced turbines is limited, causing the selling price is less competitive compared with the imported ones.

- Turbine standardization is not yet available

- Turbine license is not available

- Advanced material technology is limited

3) Opportunities: Opportunities are external conditions of the turbine industry that can help achieve its strategic competitiveness. The opportunities are indicated by:

- Great energy potential in Indonesia

- Very large market potential

- Growing industrial and commercial sector

- The program on the development of electricity infrastructure of 35,000 MW can become an opportunity to advance the turbine industry in Indonesia

- Local content use (TKDN) is low

- The various Energy development program

- Opportunities for the private sector to develop a large turbine industry

- Dependence on imported turbine components is still very large.

4) Threats: Threat is an external condition of the company that can disrupt the development of the turbine industry, especially in increasing competitiveness. The threats faced include:

- More imported turbine products available in the market

- Regulation related to import of turbines 
- Indonesia's turbine competitiveness is still low

- Research quality of turbines is still low

- The turbine roadmap is not well identified

- Market globalization of turbines

- Prices of domestic products cannot compete with imported products

- Dependence on the raw material of turbine manufacturing

\section{B. Result of External Factor Evaluation (EFE) Matrix}

The results of the EFE matrix calculations that are collected and summarized from expert assessments are shown in Table 2.

TABLE II

MATRIX OF EXTERNAL FACTOR EVALUATION (EFE)

\begin{tabular}{|c|c|c|c|c|}
\hline External Strategic Factors & Weight & Rating & $\begin{array}{l}\text { Total } \\
\text { Score }\end{array}$ & Priority \\
\hline \multicolumn{5}{|c|}{ Opportunity } \\
\hline $\begin{array}{l}\text { The large energy potential in } \\
\text { Indonesia is very large }\end{array}$ & 0.0709 & 4 & 0.2570 & 1 \\
\hline The market potential is very large & 0.0562 & 3 & 0.1617 & 2 \\
\hline Industrial and commercial growth & 0.0587 & 3 & 0.1760 & 3 \\
\hline $\begin{array}{l}\text { The program to accelerate the } \\
\text { development of electricity } \\
\text { infrastructure through the } 35,000 \\
\text { MW program launched by the } \\
\text { government can be the right } \\
\text { momentum to develop the turbine } \\
\text { industry }\end{array}$ & 0.0660 & 3 & 0.2228 & 5 \\
\hline TKDN is still low & 0.0709 & 4 & 0.2570 & 7 \\
\hline $\begin{array}{l}\text { The energy program is a priority } \\
\text { program for nawacita }\end{array}$ & 0.0611 & 3 & 0.1910 & 8 \\
\hline $\begin{array}{l}\text { Private opportunities to build large } \\
\text { turbines }\end{array}$ & 0.0562 & 3 & 0.1617 & 6 \\
\hline $\begin{array}{l}\text { The dependence on imported } \\
\text { turbines is still large }\end{array}$ & 0.0611 & 3 & 0.1910 & 4 \\
\hline Total & 0.5012 & & 1.6183 & Priority \\
\hline \multicolumn{5}{|c|}{ Threat } \\
\hline Imported turbine products & 0.0709 & 4 & 0.2570 & 2 \\
\hline $\begin{array}{l}\text { Regulation of import facilities } \\
\text { related to import of turbines }\end{array}$ & 0.0709 & 4 & 0.2570 & 8 \\
\hline $\begin{array}{l}\text { Indonesia's turbine competitiveness } \\
\text { is still low }\end{array}$ & 0.0660 & 3 & 0.2228 & 5 \\
\hline The quality of research is still low & 0.0465 & 2 & 0.1103 & 6 \\
\hline The turbine roadmap is unclear & 0.0611 & 3 & 0.1910 & 7 \\
\hline $\begin{array}{l}\text { Globalization of the market in the } \\
\text { field of turbines }\end{array}$ & 0.0611 & 3 & 0.1910 & 1 \\
\hline $\begin{array}{l}\text { Prices of domestic products cannot } \\
\text { compete }\end{array}$ & 0.0611 & 3 & 0.1910 & 4 \\
\hline $\begin{array}{l}\text { Dependence on the raw material } \\
\text { for making turbines }\end{array}$ & 0.0611 & 3 & 0.1910 & 3 \\
\hline Total & 0.4988 & & 1.6112 & \\
\hline
\end{tabular}

EFE Matrix identification through evaluations on a scale of 1-4 showed an Opportunity score (1.6183) is greater than the Threat score (1.6112). The score explains that the opportunities in the turbine industry are greater than the threats so that if the opportunity can be utilized properly, it will be able to increase the TKDN of the turbine industry.

The main priority in assessing the indicators of the opportunity is the energy potential in Indonesia. The government should be able to capture this opportunity so that it can be responded to by the domestic turbine industry market. If the energy potential has been appropriately captured, the next step is to utilize the large market potential, which is the second priority, along with the increasing growth of the economy, while industry and other commercial sectors are places as the third priority. Expectations of reduced dependence on imported turbines can be a huge opportunity for the turbine industry in Indonesia, placed as the fourth priority. Furthermore, the fifth priority is the program to accelerate the development of electricity infrastructure through the 35,000 MW program, that can wider the opportunities for the private sector to build large-scale turbines, which becomes the sixth priority.

The seventh priority that needs to be intervened is the level of TKDN, which is still relatively low so that if the supporting factors can be improved, there will be opportunities to increase its level, while the eight priority is the implementation of the energy development program. The EFE matrix analysis results from the threat side consist of 8 points, and each point has been sorted according to the priority level, based on the results of discussions among the selected experts. Market globalization is the main threat factor as the turbine industry in Indonesia is not yet ready to face the challenge. Therefore, preparing the turbine industry to enter the global market is crucial.

The second priority in the threat factor is imported turbine products, where imported products from China have dominated the turbine market in Indonesia as the prices are relatively affordable. The third priority of the threat factor is the dependence of raw materials, and the fourth priority is the price of domestic products, which are not competitive. The third and fourth priorities are interrelated because the price of imported finished products is lower due to the additional tax levied on the imported raw material.

The fifth priority is a low level of competitiveness of the turbine, and the sixth priority is the inadequate quality of research. The unclear turbine roadmap is the seventh priority, and regulation of the import facility is the eighth priority.

\section{Result of Internal Factor Evaluation Matrix}

The results of the EFE matrix calculations that are collected and summarized from expert assessments are shown in Table 3. Based on Table 3, FE Matrix produces a strength score of 1.7395 and a weakness score of 1.8053 , reflecting an expert's opinion that the element of weakness is more dominant than the element of strength, which is part of internal factors.

Internal factors can be explained by eight indicators that reflect SWOT, which is compiled based on the result of FGDs that have been carried out in teamwork. The analysis shows that the score of large energy market potential is the priority in terms of internal factors. The availability of a turbine component supporting industry, which is the second priority, will improve the main objective of increasing the TKDN of turbine components. The advantages possessed by internal factors, namely the mastery of software for turbine design, is the third priority. Mastery of the turbine design software supported by quality human resources is the fourth priority. The human resources are managed by the $\mathrm{R} \& \mathrm{D}$ institution, which is the fifth priority. The sixth priority is the development of turbine technology, which is a determining factor for the local turbine manufacturing- The innovation system that should be developed becomes the seventh 
priority while increasing human resource capacity by providing training both locally and abroad is the eighth priority.

TABLE III

INTERNAL FACTOR EVALUATION MATRIX RESULT (IFE)

\begin{tabular}{|l|c|c|c|c|}
\hline \multicolumn{1}{|c|}{ Internal Strategic Factors } & Weight & Rating & $\begin{array}{c}\text { Total } \\
\text { Score }\end{array}$ & Priority \\
\hline \multicolumn{3}{|c|}{ Strength } \\
\hline Quality human resources & 0.0619 & 4 & 0.2168 & 4 \\
\hline $\begin{array}{l}\text { Turbine software related to turbine } \\
\text { design }\end{array}$ & 0.0619 & 4 & 0.2168 & 3 \\
\hline Increased HR capacity & 0.0642 & 4 & 0.2326 & 8 \\
\hline Turbine technology & 0.0575 & 3 & 0.1869 & 6 \\
\hline Large energy market potential & 0.0664 & 4 & 0.2489 & 1 \\
\hline R \& D & 0.0597 & 3 & 0.2016 & 5 \\
\hline Innovation system & 0.0575 & 3 & 0.1869 & 7 \\
\hline $\begin{array}{l}\text { The availability of industrial } \\
\text { supporting turbine components }\end{array}$ & 0.0664 & 4 & 0.2489 & 2 \\
\hline Total & $\mathbf{0 . 4 9 5 6}$ & & $\mathbf{1 . 7 3 9 5}$ & Priority \\
\hline \multicolumn{2}{|l|}{ Weakness } & & & \\
\hline Supporting policies is not optimal & 0.0686 & 4 & 0.2658 & 1 \\
\hline $\begin{array}{l}\text { There is no market guarantee for } \\
\text { industries involved in turbine } \\
\text { manufacturing }\end{array}$ & 0.0642 & 4 & 0.2326 & 2 \\
\hline $\begin{array}{l}\text { Unavailability of turbine testing } \\
\text { laboratories }\end{array}$ & 0.0708 & 4 & 0.2832 & 5 \\
\hline $\begin{array}{l}\text { Non-continuous budgeting } \\
\text { mechanism }\end{array}$ & 0.0619 & 4 & 0.2168 & 6 \\
\hline $\begin{array}{l}\text { Limitations of products produced in } \\
\text { quantity so that the selling price } \\
\text { offered cannot compete with imported } \\
\text { products }\end{array}$ & 0.0597 & 3 & 0.2016 & 8 \\
\hline There is no standardized turbine & 0.0597 & 3 & 0.2016 & 7 \\
\hline There is no license & 0.0575 & 3 & 0.1869 & 3 \\
\hline $\begin{array}{l}\text { Advanced material technology is still } \\
\text { low }\end{array}$ & 0.0619 & 4 & 0.2168 & 4 \\
\hline Total & $\mathbf{0 . 5 0 4 4}$ & & $\mathbf{1 . 8 0 5 3}$ & \\
\hline
\end{tabular}

Weakness factors have a greater score, thus becoming a top priority in overcoming weaknesses in the internal factors of developing the turbine manufacturing industry in Indonesia. The main priority is to optimize policies that support the development of the turbine industry. The second priority is that the government can guarantee a market for industries engaged in turbine manufacturing. The third priority is to get a license for the development of turbine innovation by $\mathrm{R} \& \mathrm{D}$ institutions. The fourth priority is the development of advanced material technology related to turbine technology. The fifth priority is the unavailability of turbine testing sites or laboratories, suggesting the government or private sector needs to build laboratories for turbine testing. The sixth priority is continuous budgeting to study the development of turbine technology so that it can continue. The seventh priority is the need for standardization of turbines, and the eighth priority is to increase the number of turbines produced such that the selling price of local turbines can compete with imported turbine products.

\section{Findings of SWOT Analysis}

Recognizing existing strengths and weaknesses and understanding threats and opportunities are crucial in formulating the strategy of increasing TKDN turbines into strategic steps that need to be prioritized. This is mainly intended to identify each stakeholder more specifically. After the SWOT factors were identified through the FGD [19], [20], [20] conducted to all stakeholders involved in the development of the turbine industry, the results were briefly tabulated in Table 4.

The conclusions obtained from the SWOT analysis through the IE and FE matrix are:

- Based on the results of the EFE matrix identification by giving 1-4 scale points, the Opportunity score (1.6183) is greater than the Threat score (1.6112). A comparison of scores explains that the opportunities found in the turbine industry are greater than threats. Thus, if the opportunity can be utilized or appropriately captured, it will significantly be able to increase the TKDN of the turbine industry.

- The results of the IFE matrix produce a strength score of 1.7395 and a weakness score of 1.8053 . According to expert scores, this shows that internal factors of weakness are greater than the strength factor at the national turbine industry level.

TABLE IV

TURBINE INDUSTRIAL SWOT DESCRIPTION

\begin{tabular}{|c|c|c|c|c|}
\hline No & Strength & Weaknesses & Opportunity & Threats \\
\hline 1 & $\begin{array}{l}\text { Availability of quality HR } \\
\text { turbine technology }\end{array}$ & Supporting policies is not optimal & Energy potential in Indonesia is large & $\begin{array}{l}\text { Imported turbine products } \\
\text { have developed in Indonesia }\end{array}$ \\
\hline 2 & $\begin{array}{l}\text { Turbine software technology } \\
\text { is related to turbine designs } \\
\text { that have developed }\end{array}$ & $\begin{array}{l}\text { There is no market guarantee for industries } \\
\text { engaged in turbine manufacturing }\end{array}$ & The market potential is very large & $\begin{array}{l}\text { Regulation of import facilities } \\
\text { related to import of turbines }\end{array}$ \\
\hline 3 & $\begin{array}{l}\text { Increased HR capacity in the } \\
\text { turbine field }\end{array}$ & There is no place for testing turbines & Industrial and commercial growth & $\begin{array}{l}\text { Indonesia's turbine } \\
\text { competitiveness is still low }\end{array}$ \\
\hline 4 & $\begin{array}{l}\text { Turbine technology has } \\
\text { developed in Indonesia }\end{array}$ & Non-continuous budgeting mechanism & $\begin{array}{l}\text { The program to accelerate the development of electricity } \\
\text { infrastructure through the } 35,000 \mathrm{MW} \text { program launched } \\
\text { by the government can be the right moment to move }\end{array}$ & $\begin{array}{l}\text { The quality of research in the } \\
\text { field of turbines is still low }\end{array}$ \\
\hline 5 & $\begin{array}{l}\text { Huge energy market } \\
\text { potential }\end{array}$ & $\begin{array}{l}\text { Limitations of products produced in quantity } \\
\text { so that the selling price offered cannot } \\
\text { compete with imported turbine products }\end{array}$ & TKDN is still low & $\begin{array}{l}\text { The turbine roadmap is } \\
\text { unclear }\end{array}$ \\
\hline 6 & $\begin{array}{l}\text { Support in the field of R \& } \\
\text { D turbines in Indonesia is } \\
\text { very supportive }\end{array}$ & There is no standardized turbine & The energy program is a priority program for nawacita & $\begin{array}{l}\text { Globalization of the market in } \\
\text { the field of turbines }\end{array}$ \\
\hline 7 & $\begin{array}{l}\text { Innovation systems in the } \\
\text { field of turbines are } \\
\text { increasing in Indonesia }\end{array}$ & There is no turbine license & Private opportunities to build large turbines & $\begin{array}{l}\text { Prices of domestic products } \\
\text { cannot compete with imported } \\
\text { products }\end{array}$ \\
\hline 8 & $\begin{array}{l}\text { Availability of industries } \\
\text { supporting turbine } \\
\text { components... }\end{array}$ & Advanced material technology is still low & The dependence on imported turbines is still large & $\begin{array}{l}\text { Dependence on the raw } \\
\text { material for making turbines }\end{array}$ \\
\hline
\end{tabular}


Based on the results of the SWOT analysis, W-O Strategy assumptions were chosen, namely Self-Improvement. Further explanation of Self-Improvement based on the W-O Strategy will be elaborated within the following sub-section of Assumptions in SWOT Analysis Strategy.

\section{E. Assumptions in SWOT Analysis Strategy}

Decision-makers who use SWOT should develop four types of strategies, namely:
- S-O Strategy (Strength-Opportunity Strategy)

- W-O Strategy (Weakness-Opportunity Strategy)

- S-T Strategy (Strength-Treat Strategy)

- W-T Strategy (Weakness-Treat Strategy)

Table 5 details the assumptions of the turbine industry SWOT strategy that was developed by referring to the results of the surveys, in-depth interviews, and FGDs.

TABLE V

ASSUMPTION OF SWOT STRATEGY IN TURBINE INDUSTRY

\begin{tabular}{|c|c|c|}
\hline \multirow{9}{*}{ IFE } & Strength & Weakness \\
\hline & Quality human resources & Changing policies often \\
\hline & Turbine software related to turbine design & $\begin{array}{l}\text { There is no market guarantee for industries } \\
\text { involved in turbine manufacturing }\end{array}$ \\
\hline & HR Capacity & There is no place for testing turbines \\
\hline & Turbine technology & Budgeting mechanism that is not continuous \\
\hline & Energy potential market & $\begin{array}{l}\text { The quantity so that the selling price offered } \\
\text { cannot compete with imported turbine products }\end{array}$ \\
\hline & $\mathrm{R} \& \mathrm{D}$ & There is no standardization of turbines \\
\hline & Innovation System & The absence of licensing \\
\hline & $\begin{array}{l}\text { Availability of industrial support for turbine } \\
\text { components }\end{array}$ & Advanced material technology is still low \\
\hline \multicolumn{3}{|l|}{ Opportunity } \\
\hline Large energy potential & \multirow{8}{*}{ SO Strategy } & \multirow{8}{*}{ WO Strategy } \\
\hline Big market potential & & \\
\hline Industrial and Commercial Growth & & \\
\hline $\begin{array}{l}\text { The progress of the acceleration of electricity } \\
\text { infrastructure through the progress of } 35,000 \\
\text { MW announced by the government can be the } \\
\text { right moment to move }\end{array}$ & & \\
\hline TKDN is still low & & \\
\hline $\begin{array}{l}\text { Energy progress is Nawacita's priority } \\
\text { progress }\end{array}$ & & \\
\hline Private opportunities to build large turbines & & \\
\hline $\begin{array}{l}\text { The dependence on imported turbines is still } \\
\text { large }\end{array}$ & & \\
\hline \multicolumn{3}{|l|}{ Threat } \\
\hline Turbine Import Products & \multirow{8}{*}{ ST Strategy } & \multirow{8}{*}{ WT Strategy } \\
\hline Ease of Import Facility Regulation & & \\
\hline Low Competitiveness & & \\
\hline Research quality is still low & & \\
\hline The turbine roadmap is unclear & & \\
\hline Globalization market & & \\
\hline Prices of domestic products cannot compete & & \\
\hline Dependence on raw materials & & \\
\hline
\end{tabular}

1) S-O Strategy Assumption: This strategy uses internal power to capture opportunities that exist outside the organization. In general, organizations try to implement $\mathrm{WO}$, ST, or WT strategies to establish SO strategies. Based on the results of the SWOT analysis, the assumptions used in the S-O strategy include:

- Increasing human resources capacity to obtain qualified human resources. Efforts in increasing human resource capacity through ongoing training and $\mathrm{R}$ \& D development will create strong capital for the development of turbine technology in Indonesia.

- Through mastery of turbine technology and given the large potential of the energy market, Indonesia will be able to meet the energy market to achieve the acceleration of electricity infrastructure development through the 35,000 MW program.

- Opportunities to develop the turbine industry for private sectors is considerably large. Therefore, the Government must develop existing supporting components for the turbine industry

- The growth of industry and the commercial sector give a positive signal to the development of the turbine industry.

2) W-O Strategy Assumption: This strategy aims to minimize internal weaknesses by utilizing external opportunities. The analysis in the SWOT matrix indicates that the Government of Indonesia needs to focus on the internal factor, which is the weaknesses and the external factor, namely, opportunities. The recommended strategy 
based on EFE and IFE matrices showed that W-O strategy or a self-improvement strategy become the strategy to increase the level of TKDN. Based on the results of the SWOT analysis, the assumptions of the W-O Strategy are:

- The large potential of the energy market and the $35,000 \mathrm{MW}$ program is an excellent opportunity to grow the turbine industry in Indonesia. Therefore, the government must provide market guarantees for the industry. Strategies that can be taken include requiring PLN to use the domestic market and implement import restrictions through increasing import duties. The commitment of PT PLN related to the utilization of domestic products is realized through collaboration with the Indonesian turbine industry.

- Consistent policy in implementing a continuous budgeting mechanism for HR and R\&D is required to support innovation in mastering turbine technology. This is an important role that is expected from Kemenristekdikti in supporting turbine development, so that mastery of turbine technology will contribute to increasing national competitiveness.

- Importance of obtaining a license. So that knowledge transfer can be realized in order to improve turbine technology innovation and to foster the mastery of turbine technology developed by qualified human resources, as well as capability in creating better planning of quality turbines.

- The strength factor with the availability of turbine component supporting industries requires the government to develop turbine standardization so that the component products that will be produced can be competitive in the market.

3) S-T Strategy Assumption: Through this strategy, organizations try to avoid or reduce the impact of external threats. The S-T strategy includes:

- Revision on regulations of import facilities and revision of the Government Regulation Number 20 of 2005 concerning Technology Transfer and Government Regulation No. 35 of 2007 concerning the Allocation of Part of the Business Entity's Income to Improve Indonesia's Engineering, Innovation and Diffusion Capabilities, also to provide incentives to business entities to have an impact on reducing dependence on imported products. Through the regulation of import facilities, it is expected that domestic product prices will be more competitive.

- Increasing Indonesia's turbine competitiveness which is still low, amid the market globalization that has begun to threaten the development of the turbine industry in Indonesia

- Improving the quality of research by increasing the capacity of human resources and developing R \& D of the Directorate of Higher Education (Ristekdikti)

- Establish a concise and detailed turbine roadmap to support the development of turbine technology.

4) W-T Strategy Assumption (Weakness-Threat): A strategy to survive by reducing the impact of external threats. This assumption includes:
- The government is required to optimize the support for the development of the turbine industry, including guaranteeing the market for turbine manufacturing and supporting turbines research funding.

- The government must be able to provide a turbine testing site/laboratory so that researchers are able to use the required facilities and to ensure the quality of the turbines produced is satisfied quickly and efficiently.

- Continuously development of turbine technology production complies with the standards.

- The government obtained a license for the development process of the standardized turbine industry in Indonesia.

- Improvement thof e mastery level on the technology of advanced materials to reduce the dependence of the industry on imported products.

\section{F. Key Factors for Success (KFS)}

Analysis of the key success factors is done by taking the slices between the analysis of the assumptions of four SWOT strategies and the vision and mission Kemenristekdikti. The next step is to score and choose the ones who score high. The vision, mission, and values contained in the vision and mission of the Kemenristekdikti can be seen in Table 6, while the description of the Key Factors for Success analysis can be seen in Table 7 and Table 8.

TABLE VI

DESCRIPTION OF THE VISION OF KEMENRISTEKDIKTI

\begin{tabular}{|c|c|}
\hline $\begin{array}{l}\text { The vision of Science } \\
\text { and Technology } \\
\text { Development } 2025\end{array}$ & $\begin{array}{l}\text { "Science and Technology as the main force } \\
\text { to increase sustainable prosperity and } \\
\text { national civilization." }\end{array}$ \\
\hline $\begin{array}{l}\text { The mission of } \\
\text { Development of } \\
\text { Science and } \\
\text { Technology } 2025\end{array}$ & $\begin{array}{l}\text { - Placing Science and Technology as the } \\
\text { basis of sustainable national development } \\
\text { policies } \\
\text { - Providing an ethical foundation on the } \\
\text { development and application of Science } \\
\text { and Technology; } \\
\text { - Realizing a strong national innovation } \\
\text { system to improve the competitiveness of } \\
\text { the nation in the global era } \\
\text { - Increasing the diffusion of science and } \\
\text { technology through strengthening the } \\
\text { network of science and technology actors } \\
\text { and institutions including the } \\
\text { development of Science and Technology } \\
\text { intermediation mechanisms and } \\
\text { institutions } \\
\text { - Realizing qualified and competitive } \\
\text { human resources, facilities, infrastructure } \\
\text { and Science and Technology institutions } \\
\text { - Realizing an intelligent and creative } \\
\text { Indonesian society in a knowledge-based } \\
\text { society. }\end{array}$ \\
\hline $\begin{array}{l}\text { The values contained } \\
\text { in the vision and } \\
\text { mission }\end{array}$ & $\begin{array}{l}\text { - Indonesian competitiveness } \\
\text { - Technological innovation } \\
\text { - Policy in the field of technology } \\
\text { - Incentive research consortium } \\
\text { - Coordination/values of the research } \\
\text { consortium }\end{array}$ \\
\hline
\end{tabular}


TABLE VII

ANALYSIS OF KEY FACTORS OF SUCCESS: S-O AND S-T STRATEGY

\section{Strategy Assumptions}

\begin{tabular}{|c|c|c|c|c|c|c|c|c|c|c|c|c|c|}
\hline Vision & \multicolumn{5}{|c|}{ Mission } & \multicolumn{5}{c|}{ Values } & \multicolumn{2}{c|}{$\begin{array}{c}\text { Sequence of strategy } \\
\text { choices }\end{array}$} \\
\hline 1 & 1 & 2 & 3 & 4 & 5 & 6 & 1 & 2 & 3 & 4 & 5 & $\begin{array}{c}\text { Total } \\
\text { Score }\end{array}$ & Sequence \\
\hline
\end{tabular}

\section{S-O Strategy Assumptions}

Increasing HR capacity so that qualified human resources can be obtained, Indonesia has the potential of quality human resources, if this potential is used to improve the quality of human resources by increasing human resource capacity through continuous training and $\mathrm{R}$ \& D development it will be a strong capital for the development of turbine technology in Indonesia.

Mastery of the turbine technology that is already owned, especially seeing the enormous potential of the energy market, Indonesia will be able to reach the energy market to achieve the acceleration of the electricity infrastructure development program through the 35,000 MW program launched by the government.

Private opportunities in building the turbine industry are still very large, for this reason, the government must develop an industry supporting existing turbine components.

Increased industrial and commercial growth provides a positive signal in the development of the turbine industry.

\section{S-T Strategy Assumptions}

Revise regulations on import facilities to have an impact on reducing dependence on imported products. With the regulation of import facilities on the imported raw materials for the turbine industry, so that domestic product prices can compete.

The competitiveness that is still low and the threat of market globalization that is in sight is a threat to the development of the turbine industry in Indonesia.

Improving the quality of research by increasing HR capacity and developing R \& D owned by Ristekdikti.

4. Making a clearer and more planned turbine roadmap so that the process of developing turbine technology is more directed.

\begin{tabular}{|l|l|l|l|l|l|l|l|l|l|l|l|l|l|}
\hline 4 & 4 & 4 & 4 & 4 & 4 & 4 & 4 & 4 & 4 & 4 & 4 & 48 & \\
\hline 4 & 4 & 4 & 3 & 4 & 4 & 3 & 4 & 4 & 4 & 4 & 4 & 46 & 6 \\
\hline 3 & 2 & 2 & 3 & 2 & 2 & 4 & 4 & 3 & 4 & 3 & 4 & 36 & 16 \\
\hline
\end{tabular}

\begin{tabular}{|c|c|c|c|c|c|c|c|c|c|c|c|c|c|}
\hline 4 & 2 & 3 & 4 & 3 & 2 & 3 & 4 & 3 & 4 & 3 & 3 & 38 & 14 \\
\hline 4 & 2 & 4 & 4 & 3 & 3 & 3 & 4 & 3 & 4 & 4 & 4 & 42 & 12 \\
\hline 4 & 4 & 4 & 4 & 4 & 4 & 3 & 4 & 4 & 4 & 4 & 4 & 47 & 4 \\
\hline
\end{tabular}

TABLE VIII

ANALYSis OF SUCCESS Key FACTORS: W-O AND W-T STRATEGY

\section{Strategy Assumptions}

\begin{tabular}{|c|c|c|c|c|c|c|c|c|c|c|c|c|c|}
\hline Vision & \multicolumn{5}{|c|}{ Mission } & \multicolumn{4}{c|}{ Values } & \multicolumn{3}{c|}{$\begin{array}{c}\text { Sequence of } \\
\text { strategy choices }\end{array}$} \\
\hline $\mathbf{1}$ & $\mathbf{1}$ & $\mathbf{2}$ & $\mathbf{3}$ & $\mathbf{4}$ & $\mathbf{5}$ & $\mathbf{6}$ & $\mathbf{1}$ & $\mathbf{2}$ & $\mathbf{3}$ & $\mathbf{4}$ & $\mathbf{5}$ & $\begin{array}{c}\text { Total } \\
\text { Score }\end{array}$ & Sequence \\
\hline
\end{tabular}

\section{W-O Strategy Assumptions}

Large market potential and 35,000 MW program, which is a big opportunity in the growth of the turbine industry in Indonesia, so the government must provide market guarantees for the turbine industry in Indonesia by way of requiring PLN to use the domestic market, import restrictions, increasing entry costs.

The need for consistent policies and policy implementation in a continuous budgeting mechanism is needed to support innovation in mastering turbine technology developed by HR and R \& D of Research and Technology.

The importance of obtaining a license to increase turbine technology innovation developed by qualified HR.

With the strength of the availability of the industry supporting the turbine component, the government must prepare standardized turbines, so that the turbine supporting component products can be competitive.

\section{W-T Strategy Assumptions}

The government must optimize support for the development of the turbine industry, including ensuring the market for industries engaged in turbine manufacturing.

The government must be able to provide a place for testing turbines so that the R \& D who develop turbine technology are guaranteed the quality of the turbines produced quickly and efficiently.

The need for an uninterrupted budgeting mechanism or ongoing support so that the development of turbine technology continues to be carried out and produce turbines that comply with the standards.

The need for the government to obtain a license for the standardized development process of the turbine industry in Indonesia.

Improving the technology of advanced materials that are still low to reduce the industry's dependence on imported products.

\begin{tabular}{|c|c|c|c|c|c|c|c|c|c|c|c|c|c|}
\hline 4 & 2 & 3 & 3 & 4 & 3 & 2 & 2 & 2 & 4 & 3 & 4 & 36 & 17 \\
\hline 4 & 4 & 4 & 3 & 4 & 4 & 3 & 4 & 4 & 4 & 4 & 4 & 46 & 7 \\
\hline 4 & 4 & 4 & 4 & 4 & 4 & 4 & 4 & 4 & 4 & 4 & 4 & 48 & 2 \\
\hline 4 & 4 & 4 & 4 & 4 & 3 & 4 & 4 & 4 & 4 & 4 & 4 & 47 & 3 \\
\hline
\end{tabular}

\begin{tabular}{|c|c|c|c|c|c|c|c|c|c|c|c|c|c|}
\hline 4 & 4 & 3 & 4 & 4 & 4 & 4 & 4 & 3 & 4 & 4 & 4 & 46 & 8 \\
\hline 4 & 4 & 4 & 3 & 4 & 4 & 4 & 4 & 3 & 4 & 4 & 3 & 45 & 10 \\
\hline 4 & 4 & 4 & 3 & 4 & 4 & 4 & 3 & 3 & 4 & 4 & 4 & 45 & 9 \\
\hline 4 & 4 & 4 & 3 & 4 & 4 & 4 & 4 & 4 & 4 & 4 & 4 & 47 & 5 \\
\hline
\end{tabular}


Based on the two tables of success key factors above, scores are set on each strategy from the highest to the lowest. Table 9 presents prioritize in the strategy assumptions.

TABLE IX

PRIORITY STRATEGY ASSUMPTIONS

\begin{tabular}{|c|c|}
\hline Strategy Assumptions & Priority \\
\hline $\begin{array}{l}\text { Increasing HR capacity so that qualified human resources can } \\
\text { be obtained, Indonesia has the potential of quality human } \\
\text { resources, if this potential is used to improve the quality of } \\
\text { human resources by increasing human resource capacity } \\
\text { through continuous training and R \& D development, it will } \\
\text { become a strong capital for turbine technology development in } \\
\text { Indonesia. }\end{array}$ & 1 \\
\hline $\begin{array}{l}\text { The importance of obtaining a license to increase turbine } \\
\text { technology innovation developed by qualified human resources. }\end{array}$ & 2 \\
\hline $\begin{array}{l}\text { With the strength of the availability of turbine component } \\
\text { supporting industries, the government must prepare } \\
\text { standardized turbines, so that the turbine supporting component } \\
\text { products can be competitive. }\end{array}$ & 3 \\
\hline $\begin{array}{l}\text { The need to create consistent policies and implementation of } \\
\text { policies in a continuous budgeting mechanism to support } \\
\text { innovation in mastering turbine technology developed by the } \\
\text { HR and R \& D of Kemenristekdikti. }\end{array}$ & 4 \\
\hline $\begin{array}{l}\text { Improve the quality of research by increasing human resource } \\
\text { capacity and developing R \& D owned by the Ministry of } \\
\text { Research, Technology and Higher Education. }\end{array}$ & 5 \\
\hline $\begin{array}{l}\text { Increasing the mastery of turbine technology that is already } \\
\text { owned, especially seeing the enormous energy market potential, } \\
\text { Indonesia will be able to reach the market and energy in order to } \\
\text { achieve the acceleration of the electricity infrastructure } \\
\text { development program through the } 35,000 \mathrm{MW} \text { program } \\
\text { launched by the government. }\end{array}$ & 6 \\
\hline $\begin{array}{l}\text { The need for the government to obtain a license for the } \\
\text { development process of the standardized turbine industry in } \\
\text { Indonesia. }\end{array}$ & 7 \\
\hline $\begin{array}{l}\text { The government must optimize support for the development of } \\
\text { the turbine industry, including guaranteeing the market for } \\
\text { industries engaged in turbine manufacturing. }\end{array}$ & 8 \\
\hline $\begin{array}{l}\text { The need for uninterrupted budgeting mechanisms or ongoing } \\
\text { support so that the development of turbine technology continues } \\
\text { to be carried out and produce turbines that comply with the } \\
\text { standards. }\end{array}$ & 9 \\
\hline $\begin{array}{l}\text { The government must be able to provide a place for testing } \\
\text { turbines so that the } R \& D \text { that develops turbine technology is } \\
\text { guaranteed the quality of turbines produced quickly and } \\
\text { efficiently. }\end{array}$ & 10 \\
\hline $\begin{array}{l}\text { Making a clearer and more planned turbine roadmap so that the } \\
\text { process of developing turbine technology is more directed. }\end{array}$ & 11 \\
\hline $\begin{array}{l}\text { Low competitiveness and the threat of market globalization that } \\
\text { are in sight are a threat in the development of the turbine } \\
\text { industry in Indonesia. }\end{array}$ & 12 \\
\hline $\begin{array}{l}\text { Improving the technology of advanced materials is still low to } \\
\text { reduce the dependence of the industry on imported products. }\end{array}$ & 13 \\
\hline $\begin{array}{l}\text { Revise regulations on import facilities to have an impact on } \\
\text { reducing dependence on imported products. With the regulation } \\
\text { of import facilities on the imported raw materials for the turbine } \\
\text { industry, so that domestic product prices can compete. }\end{array}$ & 14 \\
\hline $\begin{array}{l}\text { Increased industrial and commercial growth provides a positive } \\
\text { signal in the development of the turbine industry }\end{array}$ & 15 \\
\hline $\begin{array}{l}\text { Private opportunities in building the turbine industry are still } \\
\text { very large, for this reason the government must develop an } \\
\text { industry supporting existing turbine components. }\end{array}$ & 16 \\
\hline $\begin{array}{l}\text { The huge market potential and the } 35,000 \mathrm{MW} \text { program are a } \\
\text { big opportunity in the growth of the turbine industry in } \\
\text { Indonesia, so the government must provide market guarantees } \\
\text { for the turbine industry in Indonesia by requiring PLN to use the } \\
\text { domestic market, import restrictions, increasing entry costs. }\end{array}$ & 17 \\
\hline
\end{tabular}

\section{G. Goal Setting}

Setting goals is obtained from the results of the highest score of the strategy assumption analysis with the mission of Table 10 provide details of the goal setting.

TABLE X

POINTS IN DETERMINING THE GOAL

\begin{tabular}{|c|c|}
\hline \multirow{7}{*}{$\begin{array}{c}\text { Kemenristekdikti } \\
\text { Mission }\end{array}$} & Key Factors for Success \\
\hline & $\begin{array}{l}\text { Increasing HR capacity so that qualified human } \\
\text { resources can be obtained, Indonesia has the } \\
\text { potential of quality human resources; if this } \\
\text { potential is used to improve the quality of human } \\
\text { resources through continuous training and R \& D } \\
\text { development, it will become a strong capital for } \\
\text { the development of turbine technology in } \\
\text { Indonesia. }\end{array}$ \\
\hline & $\begin{array}{l}\text { The importance of obtaining a license in order to } \\
\text { increase turbine technology innovation developed } \\
\text { by qualified human resources. }\end{array}$ \\
\hline & $\begin{array}{l}\text { With the strength of the availability of turbine } \\
\text { component supporting industries, the government } \\
\text { must prepare standardized turbines, so that the } \\
\text { turbine supporting component products can be } \\
\text { competitive. }\end{array}$ \\
\hline & $\begin{array}{l}\text { The need for consistent policies and policy } \\
\text { implementation in a continuous budgeting } \\
\text { mechanism is needed to support innovation in } \\
\text { mastering turbine technology developed by the } \\
\text { Kemenristekdikti HR and R \& D. }\end{array}$ \\
\hline & $\begin{array}{l}\text { Improve the quality of research by increasing } \\
\text { human resource capacity and developing R \& D } \\
\text { owned by the Ministry of Research, Technology } \\
\text { and Higher Education. }\end{array}$ \\
\hline & $\begin{array}{l}\text { Increasing the mastery of turbine technology that is } \\
\text { already owned, especially seeing the enormous } \\
\text { energy market potential, Indonesia will be able to } \\
\text { reach the market and energy in order to achieve the } \\
\text { acceleration of the electricity infrastructure } \\
\text { development program through the } 35,000 \mathrm{MW} \\
\text { program launched by the government. }\end{array}$ \\
\hline $\begin{array}{l}\text { Placing science and } \\
\text { technology as the basis of } \\
\text { sustainable national }\end{array}$ & $\begin{array}{l}\text { Improve the quality of human resource capacity } \\
\text { since sustainable national development policies }\end{array}$ \\
\hline
\end{tabular}

sustainable national

development policies;

Realizing a strong

national innovation

system to improve the

competitiveness of the

nation in the global era;

Provide an ethical

foundation on the

development and

application of science and

technology;

since sustainable national development policies

Obtain a license in order to increase national innovation in turbine technology developed by qualified human resources.

Develop standardization of turbines as a turbine science and technology foundation in the framework of developing and implementing science and technology to improve science and
competitiveness;

Increasing the diffusion of

science and technology

through strengthening the network of science and

technology actors and

institutions including the

development of science

and technology

intermediation institutions

and institutions;

Realizing quality and

competitive human

resources, facilities and

infrastructure and science

and technology

institutions;

Realizing an intelligent

and creative Indonesian

society in a knowledge-

based society.
Improving the quality of research, through the diffusion of science and technology, strengthening the network of science and technology actors and institutions including the development of mechanisms and institutions for science and technology intermediation;

Realizing HR policies, facilities, infrastructure, that are consistent to support innovation in mastering turbine technology

Improve the mastery of turbine technology that is already owned in order to realize a smart and creative Indonesian society science and technology institutions and budgeting 


\section{H. Balanced Scorecard}

To enhance the competitiveness of a company or business unit further, it requires the application of appropriate, competitive, and comprehensive strategies and in line with the vision and mission of the corresponding business unit concerned. To establish a proper, competitive, and global management strategy, the first thing to do is to measure the company's performance. Performance measurement plays an important role that ensures the success of the company's approach [19]. To obtain the right management strategy and following the vision and mission of the business unit concerned, the existing performance measurement method must be able to measure the performance of the business unit from all aspects so that the overall condition of the business unit is recognized. The application of a Balanced Scorecard as a performance measurement tool is the most appropriate solution.

The purpose of the Balanced Scorecard is to provide a precise set of balanced perspectives concerning the implementation of the objectives to increase TKDN of the turbine industry. Balanced Scorecard acts as a tool of an organization that can be used to measure performance by involving integrated factors as a tool in planning strategies to achieve goals in increasing TKDN. SWOT analysis produces interrelated strategies between four perspectives, namely the consumer perspective, internal processes perspective, learning and growth perspective, and finance perspective. The following is the explanation of the four Balanced Scorecard perspectives:

1) Customer Perspective: The target from the customer perspective is high customer satisfaction as an impact of highly competitive turbine products. The Key Performance Indicator (KPI) of the perspective are, among others, increasing local content and increasing export products (markets: PLN, Independent Power Purchase (IPP), Private).

2) Internal Process Perspective: The objective of the internal process perspective is to improve coordination between the government, the private sector. The KPI, among others, are:

- The number of consortiums produced
- Strengthening consortium research and establishing all types of turbine industry networks, including steam, water, and gas turbine.

- Strengthening and increasing innovation incentives

- Downstream of turbine products (steam, water, and gas)

- Policy evaluation by involving all stakeholders, namely revision of Law No. 2 of 2002, Ministry of Finance (MoF) Regulation No. 35/PMK.010/2017 (PMK-35) regarding the Luxury-goods Sales Tax (LST) on Luxury Goods Other Than Motor Vehicles, Government Regulation Number 20 of 2005 concerning Technology Transfer and implementing and disseminating the Regulation of the Minister of Industry Number 54 of 2012 regarding TKDN and obtaining turbine license.

3) Learn and Growth Perspective: The target of the learn and growth perspective is to improve and train the Research and Technology Human Resources. The KPI included:

- Overseas training

- 30 training and capacity building program

- Competency enhancement

- Improvement of facilities and infrastructure (software, turbine testing site)

4) Finance Perspective: The objective of the financial perspective is the provision of research incentives, innovation incentives, consortium incentives with a KPI $10 \%$ for the research budget for turbine development.

The following figure is the Strategy Map to increase TKDN turbines.

\section{Compiling Balanced Scorecard}

In the concept of the balanced scorecard, the formulated vision and mission are translated into a few strategic goals. Strategic goals are defined as statements about what you want to achieve (strategic goals in terms of output/outcome) or what you want to do (strategic objectives in terms of processes) or what you should have (strategic objectives in terms of input).

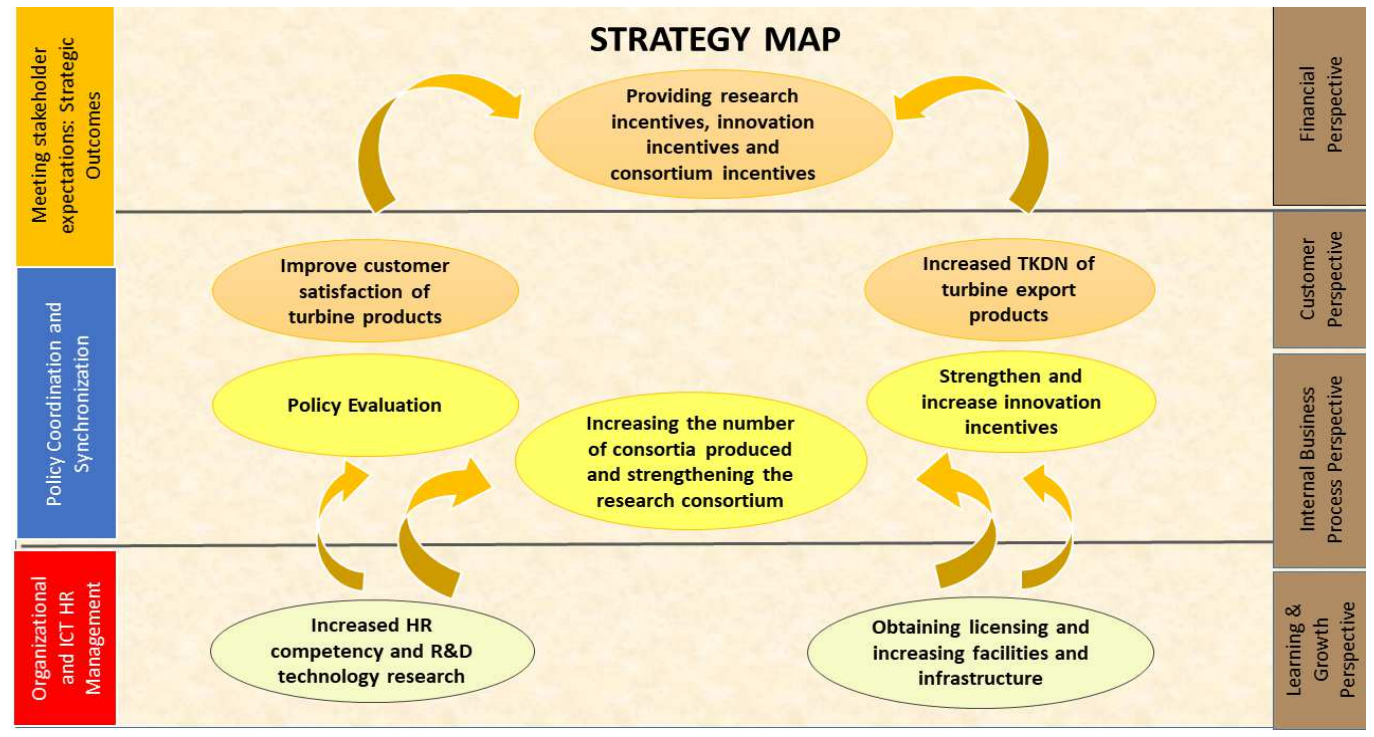

Fig. 5. Strategy Map of Balanced Scorecard 
TABLE XI

STRUCTURE OF BALANCED SCORECARD

\begin{tabular}{|c|c|c|c|c|c|c|c|}
\hline Perspective & Strategic target & Weight & Work Indicator & $\begin{array}{c}\text { Target/ } \\
\text { Objective }\end{array}$ & Initiative & Realization & Score \\
\hline \multirow{2}{*}{ Financial } & \multirow{2}{*}{$\begin{array}{l}\text { Providing research } \\
\text { incentives, innovation } \\
\text { incentives, consortium } \\
\text { incentives }\end{array}$} & \multirow{2}{*}{30} & $\begin{array}{l}\text { 1. } 10 \% \text { of the research } \\
\text { budget for turbine } \\
\text { development }\end{array}$ & $100 \%$ & Timely budgeting & $50 \%$ & \multirow{2}{*}{16.50} \\
\hline & & & $\begin{array}{l}\text { 2. Availability of } \\
\text { continuous research } \\
\text { incentives }\end{array}$ & $100 \%$ & $\begin{array}{l}\text { Preparation of } \\
\text { implementation of } \\
\text { incentives }\end{array}$ & $60 \%$ & \\
\hline \multirow[t]{2}{*}{ Customer } & \multirow[t]{2}{*}{$\begin{array}{l}\text { High customer } \\
\text { satisfaction / highly } \\
\text { competitive turbine } \\
\text { products }\end{array}$} & \multirow[t]{2}{*}{20} & increase in TKDN & $50 \%$ & $\begin{array}{l}\text { Establishment of } \\
\text { domestic turbine industry } \\
\text { and turbines } \\
\text { standardization } \\
\text { preparation }\end{array}$ & $40 \%$ & \multirow[t]{2}{*}{15.50} \\
\hline & & & Increase export products & $40 \%$ & $\begin{array}{l}\text { Increasing support for the } \\
\text { turbine support industry }\end{array}$ & $30 \%$ & \\
\hline \multirow{3}{*}{$\begin{array}{c}\text { Internal Bisnis } \\
\text { Proses }\end{array}$} & \multirow{3}{*}{$\begin{array}{l}\text { Improve coordination } \\
\text { between government, } \\
\text { private sector }\end{array}$} & \multirow{3}{*}{20} & $\begin{array}{l}\text { Increased number of } \\
\text { consortiums produced }\end{array}$ & $100 \%$ & \multirow{3}{*}{$\begin{array}{l}\text { The consortium is } \\
\text { increasing so that a } \\
\text { Turbine Network is } \\
\text { formed between } \\
\text { stakeholders in the turbine } \\
\text { industry }\end{array}$} & $50 \%$ & \multirow{3}{*}{10.67} \\
\hline & & & $\begin{array}{l}\text { Strengthen the research } \\
\text { consortium }\end{array}$ & $100 \%$ & & $60 \%$ & \\
\hline & & & $\begin{array}{l}\text { Establishment of } \\
\text { networks/networking } \\
\text { turbines (steam, water, } \\
\text { geothermal, gas) }\end{array}$ & $100 \%$ & & $50 \%$ & \\
\hline \multirow{4}{*}{$\begin{array}{l}\text { Learn and } \\
\text { growth }\end{array}$} & \multirow{4}{*}{$\begin{array}{l}\text { Increased capacity } \\
\text { and quality of human } \\
\text { resources }\end{array}$} & \multirow{4}{*}{30} & Overseas training & $100 \%$ & \multirow{3}{*}{$\begin{array}{l}\text { Support for increasing HR } \\
\text { capacity }\end{array}$} & $60 \%$ & \multirow{4}{*}{17.25} \\
\hline & & & $\begin{array}{l}30 \text { person } \mathrm{HR} \text { of industrial } \\
\text { turbine training }\end{array}$ & $100 \%$ & & $50 \%$ & \\
\hline & & & Competency enhancement & $100 \%$ & & $60 \%$ & \\
\hline & & & $\begin{array}{l}\text { Improved facilities and } \\
\text { infrastructure, obtained a } \\
\text { license (software, turbine } \\
\text { testing site) }\end{array}$ & $100 \%$ & Get a turbine testing site & $60 \%$ & \\
\hline & & 100 & & & & & \\
\hline \multicolumn{7}{|l|}{ Total Score } & 59.92 \\
\hline
\end{tabular}

A strategy map is a dashboard (instrument panel) that maps the organization's strategic goals in a framework of cause and effect relationships that describe the overall course of the organization's strategy. Strategy maps make it easy for organizations to communicate their overall strategy to all members of the organization to understand the success of achieving organizational goals. The organizational unit that prepares a strategy map is an organizational unit that defines its vision and mission clearly and has a complete management process (input resources, internal processes, and outputs/outcomes). Table 11 shows the compilation of the Balanced Scorecard.

TABLE XII

PERFormance DEgREe OF BALANCED SCORECARD

\begin{tabular}{|c|l|l|c|}
\hline No & \multicolumn{1}{|c|}{ Scale } & \multicolumn{1}{|c|}{ Performance Degree } & Color \\
\hline 1 & $>90$ & Very Successful & Blue \\
\hline 2 & $>70 \mathrm{~s} / \mathrm{d} 90$ & Successful & Green \\
\hline 3 & $>55 \mathrm{~s} / \mathrm{d} 70$ & Less Successful & Yellow \\
\hline 4 & $<55$ & Not Successful & Red \\
\hline
\end{tabular}

Based on the results of the calculation of Table 11, the degree of BSC performance level in implementing the TKDN improvement strategy in the turbine industry is on the Yellow degree, which refers to Table 12. It is considered less successful. The total score at 59.92 shows a few aspects that need to be improved or implemented through policy reviews or stipulations.

\section{CONCLUSION}

One reason for the low penetration rate of local content (TKDN) of the turbine manufacturing in Indonesia is relatively weak in mastery turbine technology. Kemenristekdikti has conducted a research study to investigate and identify the capabilities of the national turbine industry and the role of R \& D institutions in the efforts to increase the local content of turbine manufacturing. The study focuses on mapping, assessing, planning and implementing a complex industrial system which requires a sophisticated analysis tool, namely SWOT analysis and Balanced Scorecard (BSC), that can measure current and future conditions of turbine manufacturing development by considering the overall internal and external factors of industry (strengths, weaknesses, opportunities, and threats factors), technical and non-technical, financial and nonfinancial, assessing the capabilities of the turbine industry. This tool is also used to measure the performance of all operational systems involved in the turbine manufacturing 
system to produce policy recommendations to increase the TKDN level of the turbine industry in Indonesia.

The SWOT analysis result indicates that the turbine industry status in Indonesia needs improvement in the area of market guarantee provision and budgeting mechanism of turbine technology innovation through continues and consistent policy of HR and R\&D. The strategy uses WO Strategy, namely self-improvement in which is chosen based on prominent factors that come into the surface accordingly with the weakness and opportunity factors. The importance of getting a license to increase technological innovation by qualified human resources and standardization, so the turbine supporting component products can be competitive also becomes part of the suggested strategies. By setting up an appropriate mechanism to embody the suggested WO Strategy, it is expected that the level of TKDN in the turbine industry in Indonesia will be increased.

A strong and thorough set of policies to support the improvement of the utilization of turbine technology that will increase the level of competitiveness plays critical factors accordingly to the result of Balanced Scorecard. The combination of SWOT analysis and BSC resulted sit on the Yellow Degree of BSC Performance level. The score reflects that less successful approaches have been in practice suggesting that several policies need to be taken to make significant progress in the turbine manufacturing development.

This result has led to short-term and long-term policy recommendations in order to expedite the increase of TKDN. The first recommendation for the short-term program is to encourage the involvement of universities, related government institutions, Kemenristekdikti, PLN, Ministry of Energy and Mineral Resources (KESDM) and turbine manufacturing companies in Indonesia in their role in increasing TKDN, as well as preparing the budget scheme to allocate incentives for research, innovation and consortium activities. Other important recommendations are to strengthen the consortium by involving research institutions organized under some reputable universities, LPNK (nonministerial government institution), central and regional governments, and the private turbine industry, as well as to conduct training and capacity building activities.

Policies related to obtaining Licenses for manufacturing turbines in Indonesia should be imposed by appointing stateowned companies to engage with the process. Policy evaluation by involving all stakeholders is necessary, especially on the revision of Law No. 2 of 2002, Ministry of Finance (MoF) Regulation No. 35/PMK.010/2017 (PMK-35) regarding the Luxury-goods Sales Tax (LST) on Luxury Goods Other Than Motor Vehicles, Government Regulation Number 20 of 2005 concerning Technology Transfer, and implementation of the Regulation of the Minister of Industry Number 54 of 2012 regarding TKDN and obtaining turbine license.

The long-term policy recommendation suggested from the SWOT-BSC analysis provides at least four recommendations. The first one is to develop turbine technology standardization in order to increase the quality of Indonesia's competitiveness at the global level, and the second one is to increase research budgets in support of the innovation system and the quality of human resources and infrastructure. The third and the fourth recommendation consecutively are to involve research consortium to promote research on turbine technology and to build a network at the national and global level that can help increase the TKDN and encourage the turbine export products.

\section{ACKNOWLEDGMENT}

The author would like to thank the Research Center for Science, Technology and Innovation Policy and Management, Indonesian Institute of Sciences (P2KMILIPI) and the Directorate General of Innovation Strengthening of the Ministry of Research, Technology and Higher Education for supporting this research.

\section{REFERENCES}

[1] PT PLN (Persero), Rencana Usaha Penyediaan Tenaga Listrik (RUPTL) PT PLN Persero tahun 2017-2026, PLN, 2017

[2] DJK KESDM, "TKDN Ketenagalistrikan", in FGD Kajian Kemampuan Industri Turbin di Indonesia”, Jakarta, 2015

[3] Pusdatin ESDM, Handbook of Energy and Economic Statistic of Indonesia, Jakarta, 2014

[4] B2TE BPPT, "Mapping Kemampuan Industri Nasional dalam Mendukung Pembangunan Pembangkit 35.000 MW", in FGD Kajian Kemampuan Industri Turbin di Indonesia, 2015

[5] R. Sitompul. "Policy Analysis of Turbine Industry Development through Increasing Domestic Component Level (TKDN)." Kemenristekdikti, Jakarta, 2015.

[6] Ministry of Industry (MOI), Road Map Pengembangan Klaster Industri Prioritas Basis Industri Manufaktur Tahun 2010 - 2014, Jakarta, 2009.

[7] (2018) Monitorjakarta.com [Online]. Available: http://www.monitorjakarta.com/2018/03/capaian-tkdn-pembangkitlistrik-program-35-000-mw-masih-rendah/

[8] (2018) Energy on Petrominer. [Online]. Available: https://petrominer.com/mki-dorong-peningkatan-tkdn-di-proyek-35000-mw/.

[9] (2018) Kontan.co.id website. [Online]. Available: https://industri.kontan.co.id/news/soal-tkdn-pln-masih-evaluasiproyek-35000-mw.

[10] (2015) Ministry of Industry (MOI), Siaran PERS homepage on Kemeperin. [Online]. Available: http://www.kemenperin.go.id/artikel/12711/Menperin:-DongkrakTKDN,-Industri-Siap-Penuhi-Proyek-Listrik-35000-MW.

[11] Tambunan, B. "Kajian Kemampuan Industri Turbin Indonesia: Hasil Riset PTIM-BPPT" in FGD Kajian Kemampuan Industri Turbin, Kemenristek Dikti, 2015.

[12] F. Rangkuti, SWOT Balanced Scorecard: Teknik Menyusun Strategi Korporat yang Efektif Plus Cara Mengelola Kinerja dan, Jakarta, 2013.

[13] C, W. L. Hill, G. R. Jones, Essentials of Strategic Management, 2011.

[14] (2018) Mindtools.com [Online]. Available: https://www.mindtools.com/pages/article/newSTR_89.htm

[15] F. R. David, Strategic Management: Concept and Cases, 13th ed., S. Yagan, E. Svendsen, K. Norbuta, Ed. New Jersey, USA: PrenticeHall, 2011

[16] H. Koontz, H. Weihrich: Essentials Management: An International, Innovation, and Leadership, 10e Perspective, 1st e-book ed., L. Singh, Ed. New Delhi, India: McGraw-Hill Education (India) Private Limited, 2015.

[17] R. S. Kaplan, "Conceptual Foundations of the Balanced Scorecard," Working Paper of Harvard Business School, 2010.

[18] S. Zhang, C. Zhu, J. K. O. Sin, and P. K. T. Mok, "The balanced scorecard as an integrated model applied to the Portuguese public service: a case study in the waste sector," Journal of Cleaner Production, vol. 24, pp 20-29, 2012.

[19] PT PLN (Persero), "Kajian Strategis Program Pengembangan Ketenagalistrikan Nasional Dalam Rangka Pemberdayaan Industri Lokal" in FGD Kajian Kemampuan Industri Turbin di Indonesia, Jakarta, 2015.

[20] Ministry of Finance (MOF), "Fasilitas Fiskal Industri Turbin di Indonesia", in FGD Kajian Kemampuan Industri Turbin di Indonesia, Jakarta, 2015 